\title{
Central and peripheral mechanisms of narcotic antitussives: codeine-sensitive and -resistant coughs Kazuo Takahama* and Tetsuya Shirasaki
}

\author{
Address: Department of Environmental and Molecular Health Sciences, Graduate School of Pharmaceutical Sciences, Kumamoto University, 5-1 \\ Oe-Honmachi, Kumamoto 862-0973, Japan \\ Email: Kazuo Takahama* - takahama@gpo.kumamoto-u.ac.jp; Tetsuya Shirasaki - shirasak@gpo.kumamoto-u.ac.jp \\ * Corresponding author
}

Published: 9 July 2007

Cough 2007, 3:8 doi:10.1186/1745-9974-3-8

This article is available from: http://www.coughjournal.com/content/3/I/8

This is an Open Access article distributed under the terms of the Creative Commons Attribution License (http://creativecommons.org/licenses/by/2.0), which permits unrestricted use, distribution, and reproduction in any medium, provided the original work is properly cited.

\begin{abstract}
Narcotic antitussives such as codeine reveal the antitussive effect primarily via the $\mu$-opioid receptor in the central nervous system (CNS). The א-opioid receptor also seems to contribute partly to the production of the antitussive effect of the drugs. There is controversy as to whether $\delta$-receptors are involved in promoting an antitussive effect. Peripheral opioid receptors seem to have certain limited roles. Although narcotic antitussives are the most potent antitussives at present, certain types of coughs, such as chronic cough, are particularly difficult to suppress even with codeine. In guinea pigs, coughs elicited by mechanical stimulation of the bifurcation of the trachea were not able to be suppressed by codeine. In gupigs with sub-acute bronchitis caused by $\mathrm{SO}_{2}$ gas exposure, coughing is difficult to inhibit with centrally acting antitussives such as codeine. Some studies suggest that neurokinins are involved in the development of codeine-resistant coughs. However, evidence supporting this claim is still insufficient. It is very important to characterize opiate-resistant coughs in experimental animals, and to determine which experimentally induced coughs correspond to which types of cough in humans. In this review, we describe the mechanisms of antitussive effects of narcotic antitussives, addressing codeine-sensitive and -resistant coughs, and including our own results.
\end{abstract}

\section{Introduction}

Cough causes via the activation of cough reflex arc consisted of the airway vagal afferent nerves, cough center in the medulla and the efferent nerves. Inhibiting it at any site of the arc can be expected to cause antitussive effect. However, the mechanisms of cough generation, its modulation and antitussive effect of centrally and peripherally acting antitussives are still largely unclear. Of the many available narcotic and non-narcotic antitussives, the most effective are the narcotic antitussives, which are of limited use due to their inherent undesirable side effects, particularly their narcotic side effects. Even for this codeine, it has recently been pointed that it is not effective as estimated from the experimental results in guinea pigs [1]. Also, chronic coughs are often resistant to treatment with codeine. Thus, there is a need for new types of antitussives that can suppress chronic coughs. It is unclear why some coughs, such as chronic cough, are resistant even to treatment with potent antitussives such as codeine, although it is known that coughing is a neural reflex. In this review, we discuss the mechanisms of the effects of narcotic antitussives on coughing using experimental animals, and further, the resistance of coughs to narcotic antitussives, describing our recent findings regarding codeine-sensitive and -insensitive coughs in guinea pigs. 


\section{Opioid receptor subtypes and antitussive effects} The antitussive mechanisms of narcotic antitussives are not fully understood. The available evidence clearly indicates that narcotic antitussives act on opioid receptors [2$4]$. Binding studies concerning guinea-pig and human opioid receptors demonstrated that codeine and dihydrocodeine, gold standard narcotic antitussives, were more selective to the $\mu$-opioid receptor than other $\kappa$ - or $\delta$ opioid receptors $[3,5] . \mathrm{K}_{\mathrm{i}}$ value of $\left[{ }^{3} \mathrm{H}\right]$ codeine $\left(3.7 \times 10^{-7}\right.$ M) for replacement of $\left.\left[{ }^{3} \mathrm{H}\right]-\mathrm{D}-\mathrm{Ala}^{2}, \mathrm{MePhe}^{4}, \mathrm{Gly}^{2}{ }^{5}\right]$ enkephalin (DAMGO), a $\mu$-selective ligand, in guinea pigs [3] was close to the $K_{D}$ value of $5.6 \times 10^{-7} \mathrm{M}$ for the saturable binding of $\left[{ }^{3} \mathrm{H}\right]$ codeine in the lower brain stem of guinea-pigs [6]. $\mu$-Selective morphine has much more potent antitussive activity in cat [7]. $\kappa$-Agonists also have antitussive activity. Therefore, both $\mu$ - and $\kappa$-opioid receptors have been considered as candidates for being the receptors which contribute to antitussive activity.

Further, pharmacological studies carried out by using rats, mice and $\mu_{1}$-opioid receptor deficient mice suggested that $\mu_{2}$ - rather than $\mu_{1}$-subtype of the $\mu$-opioid receptor contributes to the antitussive activity of opioids $[8,9]$. Unfortunately, there is argument against these results in mice and rats, because it has been unable to reliably obtain a cough-like behavior in mice and rats. In addition, Ohi et al. [10] recently found that the motor patterns of rats and guinea pigs during cough-producing stimuli were significantly different. In rats, two different types of behavior were observed and one of them did not conform to the classic definition of a cough. Codeine suppressed both behaviors. For these reasons, it has been addressed that rats and mice are not viable as models of cough.

This issue seems to cast its shadow over the conflicting results about the role of $\delta$-opioid receptors in producing the cough inhibiting effect of narcotic antitussives. Kamei et al [11] demonstrated that [D-Pen 2,5]enkephalin (DPDPE), a selective $\delta$-agonist, did not have an antitussive effect, but rather inhibited the antitussive effects of DAMGO and K-50488H, a selective $\kappa$ opioid receptor agonist found in rats. But, $\delta$-antagonists such as naltrindole and naltriben reduced the number of capsaicin-induced coughs in mice and rats $[12,13]$. Mu- and א-opioid receptor antagonists did not antagonize the $\delta$-antagonistinduced antitussive activities. Conversely, Kotzer et al. [5] showed that the highly selective $\delta$-agonist SB 227122 inhibited the cough-reflex induced by citric acid in guinea-pigs. The antitussive effect of SB227122 was antagonized by the $\delta$-antagonist SB 244525. This $\delta$-antagonist itself did not have an antitussive effect. Kotzer et al. have also reported that naltrindole binds to human $\mu$ - and $\kappa$ opioid receptors at significant levels. Further studies are required to confirm whether the controversy presented above comes from differences in the species of experimen- tal animals used and/or differences in the pharmacological properties of each $\delta$ receptor agonist and antagonist used.

Apart from the above, we have recently found evidence for another possible mechanism of the antitussive effects of $\delta$ antagonists. In a patch clamp study using single brain neurons, naltrindole and naltriben both inhibited the currents caused by activation of G-protein-coupled inwardly rectifying $\mathrm{K}^{+}$(GIRK) channel [14]. GIRK channels couple to the $5-\mathrm{HT}_{1 \mathrm{~A}}$ receptor, and contribute to a negative feedback mechanism of 5-HT release. Dextromethorphan, which is a representative non-narcotic antitussive and has an inhibitory effect on GIRK channel activated currents [15], antagonized the 5-HT-induced hyperpolarization and depolarized the membrane potential, generating action potentials in dorsal raphe neurons. Thus, inhibition of this channel may increase the 5-HT level in the CNS. In human volunteers, infusion of 5-HT or its precursor reduced cough responses to a chloride-deficient solution [16]. In contrast, reduction of 5-HT levels has been found to inhibit the antitussive effects of narcotic and non-narcotic antitussives [17]. Stimulation of raphe nuclei depresses discharges in inspiratory motoneurons $[18,19]$. The $5-\mathrm{HT}_{1 \mathrm{~A}}$ receptor agonist inhibited cough responses, although it stimulated cough response at high doses [20]. 5- $\mathrm{HT}_{2} / 5-\mathrm{HT}_{1}$ receptor antagonists inhibited any morphine-induced antitussive effect in humans [21]. In addition, DMGO increased 5-HT efflux in dorsal raphe nucleus [22]. Taken together, the above findings suggest that antitussive effects of $\delta$-antagonists are at least partly due to the inhibition of GIRK channel currents [23].

Next, we will discuss the site of antitussive action of opioids in the CNS. Results of in vivo experiments suggest that centrally acting antitussives primarily act on the brainstem cough center. Recently, Gestreau et al. [24] reported that fictive cough selectively increased Fos-like immunoreactivity (FLI) in the interstitial and ventrolateral subdivision of the nucleus tractus solitarius (NTS), the reticular formation (the medial part of the lateral tegmental field, and the internal division of the lateral reticular nucleus), the ambigual complex (the nucleus retroambiguus, the para-ambigual region, and the retrofacial nucleus), and the medial parabrachial nucleus in cat. In all the nuclei, codeine significantly reduced the increase in FLI. Further, laryngeal afferent stimulation enhanced FLI in periaqueductal gray matter (PAG) and dorsal raphe nucleus in cat [25].

$\mu$-Opioid receptors are expressed intensely or moderately in the ambiguus nucleus, NTS, dorsal vagal nerve nucleus, medial parabrachial nucleus, PAG and raphe nuclei [2629]. In these regions, $\kappa$-opioid receptors are also expressed with similar or less potent density. $\delta$-Opioid receptors are 
generally less abundant in the brainstem, but the pneumotaxic center, including the nucleus parabrachialis, contains a very high density of $\delta$-binding site. In the NTS and ambiguus nucleus, it is expressed weakly. Here, caudal NTS and its neighboring ventromedial region has been considered as a strong candidate for being the cough center, because this region primarily receives sensory input from the lower airway [30,31] and its stimulation causes cough-like response [32,33]. The NTS is more heavily labeled by the $\mu$-ligand than by the $\kappa$-ligand in guinea pigs and cats $[29,34]$. Further, the $\mu_{2}$ sites have been found to be associated with respiratory depressant effects of opioids, whereas the $\mu_{1}$ sites have been found to be associated with the analgesic effects of opioids in mouse brain [35]. Microinjection of codeine into the NTS inhibited a fictive cough reflex in guinea pigs [36]. $\mu$-Opioid receptor agonist presynaptically inhibited excitatory postsynaptic currents in the NTS [37]. Kappa- and $\delta$-opioid receptor agonists also inhibited excitatory postsynaptic potentials in the NTS but they are less effective than $\mu$ opioid receptor agonist [38].

Given these together with the reported affinity of narcotic antitussives for opioid receptors, narcotic antitussives might have a primary site of antitussive effect on $\mu$-opioid receptors in the NTS, although there is a report that the antitussive effects of codeine are not blocked by naloxone in cats [38]. In addition to the NTS, the raphe nuclei may be a candidate for being the site of action of narcotic antitussives, since stimulation of the raphe nuclei depresses the reflex activity caused by stimulation of the superior laryngeal or vagal nerve in respiratory interneurons of the NTS, without affecting respiratory rhythm [39]. This characteristic seems to be in accordance with properties that antitussives are presumed to have.

\section{Peripheral opioid receptors and antitussive effects}

Mu-opioid receptors are located in both the central and peripheral nervous systems. Adcock [40] has written a nice review about the sensory opioid receptor and antitussive activity of narcotic antitussives. Inhalations of nebulized codeine, morphine and a peripherally acting specific $\mu$-opioid receptor agonist produced antitussive effects in guinea pigs $[41,42]$. Therefore, it is plausible that inhaled opioid antitussives exert their effect by inhibiting tachykinergic transmission of excitatory non-adrenergic non-cholinergic (eNANC) nerves via a blockade of $\mu$-opioid receptors in the airway, although it is unknown whether opioids affect peripheral opioid receptors when administered via conventional routes.

In addition to the effect on sensory fibers, opioid agonists also appear to inhibit airway cholinergic transmission [43-45]. Opioid-induced inhibition of the cholinergic bronchoconstriction induced by electric field stimulation (EFS) in guinea-pig is caused partly by an inhibitory action on the eNANC nerve, and partly by a direct effect on cholinergic transmission [44]. The inhibitory effect of $\mu$-opioid ligands on EFS-induced cholinergic contraction of the airway's smooth muscle was also found in human preparation. This effect is presumably caused by inhibiting the acetylcholine release from the postganglionic parasympathetic nerve fibers [45]. Here, controversial opinions exist as to whether the airway contraction induces a cough response or not. However, it has been known that coughing in patients with cough variant asthma [46] is inhibited by bronchodilators such as adrenergic $\beta_{2}$ stimulants [47]. This fact seems to indicate that the kind of cough such as that found in cough variant asthma may be caused by smooth muscle contraction in the airway.

Postganglionic parasympathetic nerve fibers in the airway arise from the paratracheal ganglia (PTG). Their excitability is controlled by the preganglionic neurons via central vagal reflex. In addition, they can be modulated by a peripheral reflex mechanism because the collateral branches of neurokinin-containing $\mathrm{C}$-fibers project to the PTG neurons [48] and enhance cholinergic transmission in the PTG, probably via neurokinin releases [49]. Further, we have recently found that bradykinin inhibits the $M$ type $\mathrm{K}^{+}$current in the acutely dissociated PTG neurons of rats, causing depolarization and action potential generation [50]. In addition, bradykinin potentiated nicotinic ACh currents in PTG neurons [51]. Thus, the PTG are thought to be not only a relay neuron of the parasympathetic nerve, but also integrative sites for the neuromodulation of normal airway function and important for pathogenesis in airway inflammation. Interestingly, ophiopogonin-D, an active constituent of bakumondo-to, a Chinese herbal medicine, hyperpolarized the membrane potential via activation of the $\mathrm{K}^{+}$current, reducing the cell excitability of PTG neurons [52]. Bakumondo-to is found to be effective for treating clinically chronic coughs $[53,54]$, and to inhibit codeine-registrant coughs as that expressed in the experimental model described above $[55,56]$. Therefore, we speculate that the excitability of PTG neurons may contribute to pathological condition, including some kinds of chronic cough. In this context, we examined the effects of codeine in dissociated PTG neurons. However, codeine did not induce any currents in PTG neurons, and had no effect on high-voltage-activated (HVA) $\mathrm{Ca}^{2+}$, bradykinin- induced or nicotine-induced currents in the neurons. Bradykinin-induced potentiation of nicotinic currents in the neurons was also not affected by codeine (unpublished data).

To summarize this section, $\mu$-opioid receptors locate in the airway vagal sensory neurons and, at least inhaled opi- 
oids, inhibit both eNANC nerve activity and cholinergic contraction of smooth muscles through acting on $\mu$-opioid receptors. The PTG neurons seem to be a possible target for peripherally acting antitussives. However, opioids have no effect on the PTG neurons.

\section{Codeine-sensitive and -resistant coughs}

The larynx is the most sensitive site for elicitation of the cough reflex by mechanical stimulation, followed by tracheal bifurcation and the lower half of the trachea, in that order [57]. We have recently found that coughs elicited by mechanical stimulation of the tracheal bifurcation were relatively resistant to suppression by codeine in guinea pigs, whereas mechanically induced coughs in the trachea close to the larynx were effectively inhibited by codeine [58].

Sensory receptors in airway vagal afferents have been classified into 5 groups, which include rapidly adapting receptors (RARs), A $\delta$-nociceptors and bronchial C-fiber receptors. These 3 receptors listed above appear to contribute to cough responses. RARs are myelinated A $\delta$ fibers and have a low threshold for mechanical stimuli, but are resistant to chemical stimuli. Conversely, A $\delta$-nociceptors and unmyelinated C-fiber receptors have a high threshold for mechanical stimuli, but a low threshold for chemical stimuli such as bradykinin and capsaicin. Recently, a $6^{\text {th }}$ receptor group called "cough receptor" has been identified [59]. Its properties are similar to those of RARs, but they have a slower conduction velocity and did not respond to stretching. In the larynx and upper trachea, "cough receptors" appear to play a primary role in regulation of the cough response [59]. Research by Widdicombe [57] indicated that the larynx and the tracheal bifurcation are abundantly innervated by RARs which presumably include "cough receptors". Conversely, chemoreceptors involved in cough responses are mainly distributed in the lower trachea, particularly around the tracheal bifurcation. Thus, differences in codeine resistivity between areas of the lower airway may be due to differences in the distribution of these various types of sensory fibers.

In guinea pigs, the effects of codeine on mechanically elicited coughs at each lower airway site were strengthened by repeated treatment with large doses of capsaicin [58]. This capsaicin treatment caused degeneration and dysfunction of the C- and A $\delta$-nociceptors [60-63] and consequently reduced cough generation caused by citric acid and capsaicin, but not coughs caused by nicotine or mechanical stimulation [64]. In addition, angiotensin-converting enzyme inhibitors (ACEIs), which sensitize nociceptive fibers, induced codeine-resistant chronic cough in conscious guinea pigs [65]. Consequently, it has been hypothesized that coughs mediated by nociceptive fibers were resistant to codeine. In our own study, capsaicin administered topically to the tracheal bifurcation caused a cough response that was resistant to codeine, whereas topical application to the larynx side of the trachea did not cause a cough response [66]. In a preliminary histochemical study using guinea pigs, we found that substance $P$ (SP)-like immunoreactivity is lower in the larynx side of the trachea than in the tracheal bifurcation. In addition, the density of SP-immunoreactive nerves has been found to be significantly higher in patients with cough-variant asthma than in normal subjects and patients with classic asthma [67]. The above findings support the hypothesis that coughs mediated by nociceptive fibers may be resistant to codeine treatment.

In a chronic bronchitis model of rats produced by $\mathrm{SO}_{2}$ gas exposure, SP content in the trachea was elevated [68]. In a similar model using guinea pigs, codeine did not inhibit the cough responses elicited by mechanical stimulation of the larynx side of the trachea or the tracheal bifurcation. Epithelial shedding was not observed, but neutral endopeptidase (NEP) levels and NEP activity in the trachea and bronchus were significantly lower than those of normal guinea pigs. NEP degrades a variety of peptides, including bradykinin, SP and other tachykinins [69]. At high doses, a NEP inhibitor elicits a cough response in normal guinea pigs [70]. Based on findings that bradykinin and tachykinins are potent inflammatory mediators, and that neurokinins such as SP are released from C-fiber (eNANC nerve) terminals, it has been suggested that coughing induced by inflammatory peptides is resistant to codeine. However, codeine has been found to significantly suppress the cough response induced or enhanced by NEP inhibitors [70]. In addition, opioids peripherally inhibit tachykinergic transmission in the guinea pig bronchus [71-73]. Thus, it appears that NEP inhibition or tachykinin release from peripheral C-fiber terminals is not sufficient to explain mechanisms of induction of codeineresistant cough. However, in a preliminary study, we found that inhaled neurokinin A caused codeine-resistant cough in guinea pigs. Also, in that study, co-administration of codeine and an antagonist for the neurokinin 2 $\left(\mathrm{NK}_{2}\right)$ receptor almost abolished citric acid-induced coughing in conscious guinea pigs, in spite of the fact that citric acid-induced coughs were hard to completely inhibit even with high doses of codeine, when codeine alone was given (Fig. 1).

In summary, evidence suggests that RAR or "cough receptor"-mediated coughs are sensitive to codeine but coughs triggered by neurokinin-containing nociceptive nerves are resistant to it. In support of this suggestion, there is a finding that the expression of transient receptor potential vanilloid-1 (TRPV-1) is increased in the airway nerves of patients with chronic cough [74]. In addition to TRPV-1, it has recently been reported that acid sensing ion chan- 


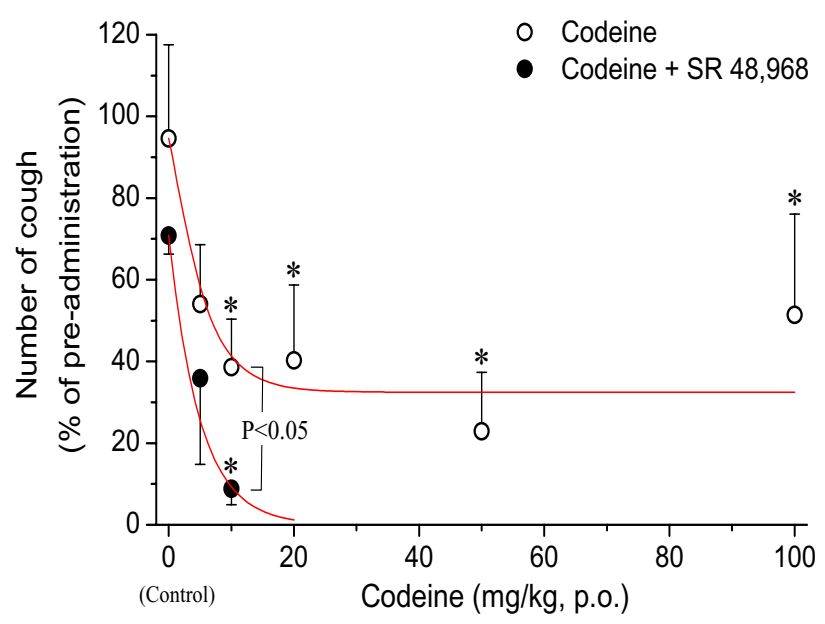

Figure I

Effect of co-administration of codeine and SR 48,968, a $\mathrm{NK}_{2}$ receptor antagonist, on citric acid-induced coughs in conscious guinea-pigs. Conscious guinea-pigs were put into plethysmograph and $10 \%$ citric acid was nebulized for 2 min to elicit a cough response. Cough number was counted for I 5 min during and after citric acid stimulation. After more than $4 \mathrm{~h}$, codeine was orally administered at various doses 30 min before the $2^{\text {nd }}$ stimulation. Then, SR 48,968 ( I mg/kg) or vehicle was intravenously administered 5 min before the $2^{\text {nd }}$ stimulation. Results were normalized to the pre-administration cough number. Continuous lines indicate the theoretical fitting of the data with single exponential function. Note that co-administration of codeine (10 mg/kg) and SR 48,968 inhibited cough response almost completely, while the antitussive effect induced by codeine alone reached a plateau at $20 \mathrm{mg} /$ $\mathrm{kg}$ (33\% of pre-administration value). Antitussive effects produced by co-administration of codeine $(10 \mathrm{mg} / \mathrm{kg})$ and SR 48,968 was significantly more potent than that produced by codeine $(10 \mathrm{mg} / \mathrm{kg})$ alone $(\mathrm{p}<0.05, \mathrm{n}=4$ and 6 , respectively). SR 48,968 itself inhibited cough response to about 70 $\%$ of the time, but the inhibitory effect was not significantly different from the vehicle group. Co-administration of codeine and SR 48,968 had no effect on mechanically-induced sneezing (data not shown). Each value shows mean \pm S.E.M. ( $n=3$ to 7$)$. $* p<0.05$, significantly different from the vehicle control.

nels (ASICs) were localized in A $\delta$-fibers of guinea pigs [75]. Therefore, differences in codeine sensitivity to acidinduced coughs may depend on the $\mathrm{pH}$ level at the chough induction site. Further studies are needed to determine a final conclusion.

\section{Codeine resistant coughs and opioid receptors}

As described in the above session, evidence suggests that tachykinin-containing vagal afferent fibers contribute to codeine-resistant cough. Such fibers rise from the airway and input the NTS $[30,31]$. Codeine-resistant coughs are caused by various conditions such as cigarette smoking, infection and inflammation of the airway. Exposure to cigarette smoke augmented the C-fiber input to the NTS [76]. Injection of a $\mathrm{NK}_{1}$ receptor antagonist into the NTS had an antitussive effect in animals exposed to cigarette smoke, but not to filtered air [77]. An excitatory action of iontophoretically applied SP on NTS neurons was not inhibited by $\mu$-agonists [78]. These findings seem to suggest that $\mu$-opioid receptors were not expressed in the $\mathrm{C}$ fiber such as tachykinin-containing fibers involved in the production of codeine-resistant cough. Furthermore, it has been reported that infection and inflammation of the airway led to the production of neurokinins in nonnociceptive RAR nerve terminals and in their cell bodies in vagal sensory ganglia [79-83]. Sensory neuropeptide release from peripheral and central endings of nonnociceptive afferent nerve seems not to require noxious or nociceptive stimuli but may occur as a result of stimulation of low-threshold mechanosensors [81]. Certainly, codeine only weakly inhibited coughs in animal models of allergic responses [84-86], as well as of chronic bronchitis produced by $\mathrm{SO}_{2}$ gas exposure [68]. Therefore, under pathological conditions described above in the airway, changes in phenotype of the vagal nerves and tachykinin release from RAR fibers might facilitate glutamatergic transmission in the nucleus involved in cough reflex, leading to codeine-resistant cough.

As described previously, $\mu$-opioid receptors are the predominant type of opioid receptor in the NTS $[87,88]$. They exist in both postsynaptic and presynaptic sites in the NTS $[38,89]$. The $\mu$-agonist activated the GIRK channel current and hyperpolarized the postsynaptic membrane potential in about $60 \%$ of NTS neurons. At the same time, $\mu$-agonists inhibited HVA $\mathrm{Ca}^{2+}$ currents in the nodose ganglia [90], and also the glutamatergic EPSCs in almost all NTS neurons via a presynaptic mechanism, which is much more sensitive to $\mu$-agonist than postsynaptic mechanisms $[37,38]$. Here, the nodose ganglion is the origin of RAR [91], and glutamate is the principal neurotransmitter in the A $\delta$-fibers [92-94]. Excision of the nodose ganglion causes marked depletion of $\mu$-opioid receptors in the dorsal and medial regions of the ipsilateral caudal NTS [34]. Electron microscopy has shown that $\mu$-opioid receptors localize in the plasma membrane of the terminals of vagal afferents derived from nodose ganglia [95], but not in nociceptive fibers [96]. Considering these findings comprehensively, it seems possible that $\mu$ receptors in the NTS may not express and/or may not function in neural networks for cough production, under pathological conditions such as infection and inflammation of the airway, although the receptors are involved in codeine-sensitive coughs under healthy conditions without infection and inflammation of the airway. 
In opposition to the idea about the relation between neurokinins and codeine-resistant cough, there is an argument based in the fact that neurokinin-containing airway fibers are very few in humans. However, neurokinin-containing vagal airway afferent neurons are only 3\% of total neurons, even in guinea-pigs [80]. Comparative study also indicated that the location of SP-immunoreactive fibers in the airway was similar between humans and guinea pigs, although SP-reactive nerves in the smooth muscle layer of the trachea and bronchi were less abundant in rat and cat than in guinea-pig [97]. In addition, as in the cases of animal models, the density of SP-immunoreactive nerves was significantly higher in patients with cough-variant asthma than in normal subjects and patients with classic asthma [67]. Increase in neurokinin content has also been observed in patients with perennial allergic rhinitis [98]. Therefore, it is reasonable to speculate that neurokinincontaining airway afferent nerves play pathophysiological roles in the generation of inflammatory and allergic airway diseases including production of codeine-resistant chronic coughs in humans.

\section{Conclusion}

Based on the above findings, we have developed the following hypothesis. Coughs mediated by mechanical stimulation of RARs or "cough receptors" are attenuated by narcotic antitussives primarily at the NTS level via inhibition of glutamatergic transmission. Presynaptic $\mu$-opioid receptors probably contribute to this inhibition. Conversely, neurokinin release in the NTS from nociceptive Cand A $\delta$-fibers, and also from RAR fibers under airway inflammation, causes coughs resistant to antitussives including opiates. Recent findings by Mazzone et al. [99] support this hypothesis. The available evidence suggests that activation of $\mu$-opioid and inhibition of neurokinin receptors can help in the suppression of some varieties of chronic cough. In a preliminary study, we found that coadministration of codeine and a $\mathrm{NK}_{2}$ tachykinin receptor antagonist abolished citric acid-induced coughs in guinea pigs, although codeine alone did not abolish the cough even when administered at very high doses. Further studies are needed to clarify the pharmacology and mechanisms of antitussive effects of opiates, and to elucidate mechanisms of opiate-resistant coughs. Furthermore, it is very important to characterize opiate-resistant coughs in experimental animals, and to determine the extent to which such experimentally induced coughs correspond to the various types of cough in humans.

\section{References}

I. Bolser DC: Cough suppressant and pharmacologic protussive therapy: ACCP evidence-based clinical practice guidelines. Chest 2006, 129:238S-249S.

2. Hennies HH, Friderichs E, Schneider J: Receptor binding, analgesic and antitussive potency of tramadol and other selected opioids. Arzneimittelforschung 1988, 38:877-880.
3. Mignat $\mathrm{C}$, Wille $\mathrm{U}$, Ziegler A: Affinity profiles of morphine, codeine, dihydrocodeine and their glucuronides at opioid receptor subtypes. Life Sci 1995, 56:793-799.

4. Schmidt H, Vormfelde S, Klinder K, Gundert-Remy U, Gleiter $\mathrm{CH}$, Skopp G, Aderjan R, Fuhr U: Affinities of dihydrocodeine and its metabolites to opioid receptors. Pharmacol Toxicol 2002, 9I:57-63.

5. Kotzer CJ, Hay DW, Dondio G, Giardina G, Petrillo P, Underwood DC: The antitussive activity of delta-opioid receptor stimulation in guinea pigs. J Pharmacol Exp Ther 2000, 292:803-809.

6. Chau TT, Carter FE, Harris LS: ${ }^{3} \mathbf{H}$-Codeine binding in the guinea pig lower brain stem. Pharmacology 1982, 25:12-17.

7. Chau TT, Carter FE, Harris LS: Antitussive effect of the optical isomers of mu, kappa and sigma opiate agonists/antagonists in the cat. J Pharmacol Exp Ther 1983, 226:108-113.

8. Kamei J, Iwamoto Y, Kawashima N, Suzuki T, Nagase H, Misawa M, Kasuya $Y$ : Possible involvement of mu 2-mediated mechanisms in mu-mediated antitussive activity in the mouse. Neurosci Lett 1993, 149:169-172.

9. Kamei J, Iwamoto Y, Suzuki T, Misawa M, Nagase H, Kasuya Y: The role of the mu 2-opioid receptor in the antitussive effect of morphine in mu I-opioid receptor-deficient CXBK mice. Eur J Pharmacol 1993, 240:99-I0I.

10. Ohi Y, Yamazaki H, Takeda R, Haji A: Phrenic and iliohypogastric nerve discharges during tussigenic stimulation in paralyzed and decerebrate guinea pigs and rats. Brain Res 2004, 1021:119-127.

II. Kamei J, Tanihara H, Kasuya Y: Modulation of mu-mediated antitussive activity in rats by a delta agonist. Eur J Pharmacol I991, 203:153-156.

12. Kamei J, Iwamoto Y, Suzuki T, Misawa M, Nagase H, Kasuya Y: Antitussive effects of naltrindole, a selective delta-opioid receptor antagonist, in mice and rats. Eur J Pharmacol 1993, 249:161-165.

13. Kamei J, Iwamoto Y, Suzuki T, Misawa M, Nagase H, Kasuya Y: Involvement of delta I-opioid receptor antagonism in the antitussive effect of delta-opioid receptor antagonists. Eur J Pharmacol 1994, 25 I:291-294.

14. Shirasaki T, Abe K, Soeda F, Takahama K: $\delta$-Opioid receptor antagonists inhibit GIRK channel currents in acutely dissociated brainstem neurons of rat. Brain Res 2004, 1006:190-197.

15. Ishibashi H, Kuwano K, Takahama K: Inhibition of the 5-HT receptor-mediated inwardly rectifying $\mathrm{K}^{+}$current by dextromethorphan in rat dorsal raphe neurones. Neuropharmacol 2000, 39:2302-2308.

16. Stone RA, Worsdell YM, Fuller RW, Barnes PJ: Effects of 5-hydroxytryptamine and 5-hydroxytryptophan infusion on the human cough reflex. J Appl Physiol 1993, 74:396-40I.

17. Kamei J, Ogawa M, Kasuya Y: Monoamines and the mechanisms of action of antitussive drugs in rats. Arch Int Pharmacodyn Ther 1987, 290: II7-I 27.

18. Lalley PM, Benacka R, Bischoff AM, Richter DW: Nucleus raphe obscurus evokes 5-HT-IA receptor-mediated modulation of respiratory neurons. Brain Res 1997, 747:156-159.

19. Lalley PM, Bischoff AM, Richter DW: 5-HT-IA receptor-mediated modulation of medullary expiratory neurones in the cat. J Physiol 1994, 476: I 17-130.

20. Stone RA, Barnes PJ, Chung KF: Effect of 5-HT IA $_{\text {receptor ago- }}$ nist, 8-OH-DPAT, on cough responses in the conscious guinea pig. Eur J Pharmacol 1997, 332:20I-207.

21. O'Connell F: Central pathways for cough in man - unanswered questions. Pulm Pharmacol Ther 2002, 15:295-301.

22. Tao $\mathrm{R}$, Auerbach $\mathrm{SB}$ : $\mu$-Opioids disinhibit and kappa-opioids inhibit serotonin efflux in the dorsal raphe nucleus. Brain Res 2005, 1049:70-79.

23. Takahama K: Mechanisms of actions of centrally acting antitussives - electrophysiological and neurochemical analysis. In Cough: Causes, Mechanisms and Therapy Edited by: Boushey H, Chung, KF, Widdicombe J. Oxford: Blackwell Publishing; 2003:225-236.

24. Gestreau C, Bianchi AL, Grelot L: Differential brainstem Fos-like immunoreactivity after laryngeal-induced coughing and its reduction by codeine. J Neurosci 1997, 17:9340-9352.

25. Ambalavanar R, Tanaka Y, Damirjian M, Ludlow CL: Laryngeal afferent stimulation enhances Fos immunoreactivity in periaqueductal gray in the cat. J Comp Neurol 1999, 409:4 I I-423. 
26. Sim LJ, Childers SR: Anatomical distribution of mu, delta, and kappa opioid- and nociceptin/orphanin FQ-stimulated [ $\left.{ }^{35} \mathrm{~S}\right]$ guanylyl-5'-O-(gamma-thio)-triphosphate binding in guinea pig brain. J Comp Neurol 1997, 386:562-572.

27. Peckys D, Landwehrmeyer GB: Expression of mu, kappa, and delta opioid receptor messenger RNA in the human CNS: a 33P in situ hybridization study. Neuroscience 1999, 88: 1093-I I 35.

28. Mansour A, Fox CA, Akil H, Watson SJ: Opioid-receptor mRNA expression in the rat CNS: anatomical and functional implications. Trends Neurosci 1995, 18:22-29.

29. Sales N, Riche D, Roques BP, Denavit-Saubie M: Localization of mu- and delta-opioid receptors in cat respiratory areas: an autoradiographic study. Brain Res 1985, 344:382-386.

30. Helke CJ, Jacobowitz DM, Thoa NB: Capsaicin and potassium evoked substance $P$ release from the nucleus tractus solitarius and spinal trigeminal nucleus in vitro. Life Sci I98I, 29:1779-1785.

31. Saria A, Martling CR, Yan Z, Theodorsson-Norheim E, Gamse R, Lundberg JM: Release of multiple tachykinins from capsaicin-sensitive sensory nerves in the lung by bradykinin, histamine, dimethylphenyl piperazinium, and vagal nerve stimulation. Am Rev Respir Dis 1988, 137:1330-1335.

32. Chakravarty NK, Matallana A, Jensen R, Borison HL: Central effects of antitussive drugs on cough and respiration. J Pharmacol Exp Ther 1956, I I 7: I27-135.

33. Kase Y, Wakita Y, Kito G, Miyata T, Yuizono T, Kataoka M: Centrally-induced coughs in the cat. Life Sci 1970, 9:49-59.

34. Dashwood MR, Muddle JR, Spyer KM: Opiate receptor subtypes in the nucleus tractus solitarii of the cat: the effect of vagal section. Eur J Pharmacol 1988, I55:85-92.

35. Moskowitz AS, Goodman RR: Autoradiographic distribution of $\mu_{1}$ and $\mu_{2}$ opioid binding in the mouse central nervous system. Brain Res 1985, 360: I 17-129.

36. Ohi Y, Yamazaki $\mathrm{H}$, Takeda R, Haji A: Functional and morphological organization of the nucleus tractus solitarius in the fictive cough reflex of guinea pigs. Neurosci Res 2005, 53:20I-209.

37. Glatzer NR, Smith BN: Modulation of synaptic transmission in the rat nucleus of the solitary tract by endomorphin-I. J Neurophysiol 2005, 93:2530-2540.

38. Rhim H, Glaum SR, Miller RJ: Selective opioid agonists modulate afferent transmission in the rat nucleus tractus solitarius. J Pharmacol Exp Ther 1993, 264:795-800.

39. Sessle BJ, Ball GJ, Lucier GE: Suppressive influences from periaqueductal gray and nucleus raphe magnus on respiration and related reflex activities and on solitary tract neurons, and effect of naloxone. Brain Res 198I, 216:145-161.

40. Adcock J]: Peripheral opioid receptors and the cough reflex. Respir Med |99|, 85(Suppl A):43-46.

4I. Karlsson JA, Lanner AS, Persson CG: Airway opioid receptors mediate inhibition of cough and reflex bronchoconstriction in guinea pigs. J Pharmacol Exp Ther 1990, 252:863-868.

42. Callaway JK, King RG, Boura AL: Evidence for peripheral mechanisms mediating the antitussive actions of opioids in the guinea pig. Gen Pharmacol 1991, 22:1 I03-1 I08.

43. Johansson IG, Grundstrom N, Andersson RG: Both the cholinergic and non-cholinergic components of airway excitation are inhibited by morphine in the guinea-pig. Acta Physiol Scand 1989, | 35:4||-4|5.

44. Belvisi MG, Stretton CD, Barnes PJ: Modulation of cholinergic neurotransmission in guinea-pig airways by opioids. $\mathrm{Br} J$ Pharmacol 1990, 100:131-137.

45. Belvisi MG, Stretton CD, Verleden GM, Ledingham SJ, Yacoub MH, Barnes PJ: Inhibition of cholinergic neurotransmission in human airways by opioids. J Appl Physiol 1992, 72:1096-I I00.

46. Corrao WM, Braman SS, Irwin RS: Chronic cough as the sole presenting manifestation of bronchial asthma. N Engl J Med I979, 300:633-637.

47. Irwin RS, French CT, Smyrnios NA, Curley FJ: Interpretation of positive results of a methacholine inhalation challenge and week of inhaled bronchodilator use in diagnosing and treating cough-variant asthma. Arch Intern Med 1997, 157:1981-1987.

48. Kummer W, Fischer A, Kurkowski R, Heym C: The sensory and sympathetic innervation of guinea-pig lung and trachea as studied by retrograde neuronal tracing and double-labelling immunohistochemistry. Neuroscience 1992, 49:7| 5-737.
49. Canning B], Reynolds SM, Anukwu LU, Kajekar R, Myers AC: Endogenous neurokinins facilitate synaptic transmission in guinea pig airway parasympathetic ganglia. Am J Physiol Regul Integr Comp Physiol 2002, 283:R320-330.

50. Mochidome T, Ishibashi H, Takahama K: Bradykinin activates airway parasympathetic ganglion neurons by inhibiting M-currents. Neuroscience 200I, 105:785-79I.

51. Zhou J, Shirasaki T, Soeda F, Takahama K: Potentiation of nicotinic currents by bradykinin in the paratracheal ganglia neurons of rats. Eur J Pharmacol 2006, 531:96-102.

52. Ishibashi H, Mochidome T, Okai J, Ichiki H, Shimada H, Takahama K: Activation of potassium conductance by ophiopogonin-D in acutely dissociated rat paratracheal neurones. $\mathrm{Br} J$ Pharmacol 200I, 132:46I-466.

53. Asano T, Murayama T, Hirai $Y$, Shoji J: Comparative studies on the constituents of ophiopogonis tuber and its congeners. VIII. Studies on the glycosides of the subterranean part of Ophiopogon japonicus Ker-Gawler cv. Nanus. Chem Pharm Bull (Tokyo) 1993, 41:566-570.

54. Mizushima Y, Hirata A, Hori T, Sawazaki S, Sugiyama E, Kobayashi M: Antitussive effect of herbal medicine bakumondo-to: a case report. Am J Chin Med 1996, 24:32I-325.

55. Miyata T, Isohama Y, Tai S, Kai H, Takahama K: Pharmacological evaluation of Bakumondo-to (Mai-men-dong-tang) as a curative for chronic inflammatory airway disease. In Pharmacological Research on Traditional Herbal Medicines Edited by: Watanabe $\mathrm{H}$, Shibuya T. Australia: Horwood Academic Publishers; 1999: I2I-147.

56. Miyata T, Fuchikami J, Kai H, Takahama K: Composition of antitussive effects of Bakumondo-to and codeine in bronchitic animals. Jpn J Thoracic Disease 1989, 27: I I57-I I62.

57. Widdicombe JG: Respiratory reflexes from the trachea and bronchi of the cat. J Physiol 1954, I 23:55-70.

58. Takahama K, Wakuda I, Fukushima $\mathrm{H}$, Isohama $\mathrm{Y}, \mathrm{Kai} H$, Miyata $\mathrm{T}$ : Differential effect of codeine on coughs caused by mechanical stimulation of two different sites in the airway of guinea pigs. Eur J Pharmacol 1997, 329:93-97.

59. Canning B], Mazzone SB, Meeker SN, Mori N, Reynolds SM, Undem $B]$ : Identification of the tracheal and laryngeal afferent neurones mediating cough in anaesthetized guinea-pigs. J Physiol 2004, 557:543-558.

60. Jancso G: Pathobiological reactions of C-fibre primary sensory neurones to peripheral nerve injury. Exp Physiol 1992, 77:405-431.

61. Jancso G, Kiraly E, Jancso-Gabor A: Pharmacologically induced selective degeneration of chemosensitive primary sensory neurones. Nature 1977, 270:74I-743.

62. Lundberg JM, Saria A: Capsaicin-induced desensitization of airway mucosa to cigarette smoke, mechanical and chemical irritants. Nature 1983, 302:251-253

63. Maggi CA, Meli A, Santicioli P: Four motor effects of capsaicin on guinea-pig distal colon. Br J Pharmacol I987, 90:65 I-660.

64. Forsberg K, Karlsson JA, Theodorsson E, Lundberg JM, Persson CG: Cough and bronchoconstriction mediated by capsaicin-sensitive sensory neurons in the guinea-pig. Pulm Pharmacol 1988, I:33-39.

65. Fox AJ, Lalloo UG, Belvisi MG, Bernareggi M, Chung KF, Barnes PJ: Bradykinin-evoked sensitization of airway sensory nerves: a mechanism for ACE-inhibitor cough. Nat Med 1996, 2:8।4-817.

66. Wakuda I, Takahama K, Isohama Y, Miyata T: Pharmacological discrimination of cough reflexes induced by topically applied chemical stimuli to the guinea pig airways. Jpn J Pharmacol 1994, 46: I 48P.

67. Lee SY, Kim MK, Shin C, Shim JJ, Kim HK, Kang KH, Yoo SH, In KH: Substance P-immunoreactive nerves in endobronchial biopsies in cough-variant asthma and classic asthma. Respiration 2003, 70:49-53.

68. Killingsworth CR, Paulauskis JD, Shore SA: Substance $\mathbf{P}$ content and preprotachykinin gene-I mRNA expression in a rat model of chronic bronchitis. Am J Respir Cell Mol Biol 1996, 14:334-340.

69. Matsas R, Kenny AJ, Turner AJ: The metabolism of neuropeptides. The hydrolysis of peptides, including enkephalins, tachykinins and their analogues, by endopeptidase-24. I I. Biochem J 1984, 223:433-440.

70. Takahama K, Fuchikami J, Kai H, Isohama Y, Miyata T: Inhalation of phosphoramidon, a neutral endopeptidase inhibitor, induces 
cough in awake guinea-pigs. Arch Int Pharmacodyn Ther 1995, 330:24I-250.

71. Kamikawa Y, Shimo Y: Morphine and opioid peptides selectively inhibit the non-cholinergically mediated neurogenic contraction of guinea-pig isolated bronchial muscle. J Pharm Pharmacol 1990, 42:214-216.

72. Frossard N, Barnes PJ: Mu-opioid receptors modulate noncholinergic constrictor nerves in guinea-pig airways. Eur J Pharmacol 1987, I41:519-522.

73. Belvisi MG, Ichinose M, Barnes PJ: Modulation of non-adrenergic, non-cholinergic neural bronchoconstriction in guinea-pig airways via $\mathbf{G A B A}_{\mathbf{B}}$-receptors. $\mathrm{Br} J$ Pharmacol 1989, 97:|225-|23|

74. Groneberg DA, Niimi A, Dinh QT, Cosio B, Hew M, Fischer A, Chung KF: Increased expression of transient receptor potential vanilloid-I in airway nerves of chronic cough. Am J Respir Crit Care Med 2004, 170: 1 276-1280.

75. Gu Q, Lee LY: Characterization of acid signaling in rat vagal pulmonary sensory neurons. Am J Physiol Lung Cell Mol Physiol 2006, 29I:L58-65.

76. Mutoh T, Joad JP, Bonham AC: Chronic passive cigarette smoke exposure augments bronchopulmonary C-fibre inputs to nucleus tractus solitarii neurones and reflex output in young guinea-pigs. J Physiol 2000, 523:223-233.

77. Joad JP, Munch PA, Bric JM, Evans SJ, Pinkerton KE, Chen CY, Bonham AC: Passive smoke effects on cough and airways in young guinea pigs: role of brainstem substance P. Am J Respir Crit Care Med 2004, 169:499-504.

78. Morin-Surun MP, Jordan D, Champagnat J, Spyer KM, Denavit-Saubie M: Excitatory effects of iontophoretically applied substance $P$ on neurons in the nucleus tractus solitarius of the cat: lack of interaction with opiates and opioids. Brain Res 1984, 307:388-392.

79. Undem BJ, Hunter DD, Liu M, Haak-Frendscho M, Oakragly A Fischer A: Allergen-induced sensory neuroplasticity in airways. Int Arch Allergy Immunol 1999, I I 8: I 50- I53.

80. Carr MJ, Hunter DD, Jacoby DB, Undem B]: Expression of tachykinins in nonnociceptive vagal afferent neurons during respiratory viral infection in guinea pigs. Am J Respir Crit Care Med 2002, 165:107|-1075.

8I. Myers AC, Kajekar R, Undem BJ: Allergic inflammation-induced neuropeptide production in rapidly adapting afferent nerves in guinea pig airways. Am J Physiol Lung Cell Mol Physiol 2002, 282:L775-78।.

82. Dinh QT, Mingomataj E, Ouarcoo D, Groneberg DA, Witt C, Klapp $B F$, Braun $A$, Fischer A: Allergic airway inflammation induces tachykinin peptides expression in vagal sensory neurons innervating mouse airways. Clin Exp Allergy 2005, 35:820-825.

83. Dinh QT, Groneberg DA, Peiser C, Springer J, Joachim RA, Arck PC, Klapp BF, Fischer A: Nerve growth factor-induced substance $P$ in capsaicin-insensitive vagal neurons innervating the lower mouse airway. Clin Exp Allergy 2004, 34: | 474- 1479.

84. Kamei J, Morita K, Kashiwazaki T, Ohsawa M: Antitussive effect of moguisteine on allergic coughs in the guinea pig. Eur J Pharmacol 1998, 347:253-255.

85. Winter CA, Flataker L. The effects of drugs upon a graded cough response obtained in sensitized guinea pigs exposed to aerosol of specific antigen. J Exp Med 1955, I0I:17-24.

86. Myou S, Fujimura M, Kurashima K, Kita T, Tachibana H, Ishiura Y, Abo $M$, Nakao S: Effects of suplatast tosilate, a new type of antiallergic agent, on airway cough hypersensitivity induced by airway allergy in guinea-pigs. Clin Exp Allergy 200I, 31:1939-1944.

87. Hassen AH, Feuerstein G, Faden Al: $\mu$ Receptors and opioid cardiovascular effects in the NTS of rat. Peptides 1982, 3:1031-1037.

88. Xia Y, Haddad GG: Ontogeny and distribution of opioid receptors in the rat brainstem. Brain Res 1991, 549:181-193.

89. Cheng PY, Liu-Chen LY, Chen C, Pickel VM: Immunolabeling of mu opioid receptors in the rat nucleus of the solitary tract: extrasynaptic plasmalemmal localization and association with Leu ${ }^{5}$-enkephalin. J Comp Neurol 1996, 371:522-536.

90. Rusin $\mathrm{KI}$, Moises HC: Mu-opioid and $\mathrm{GABA}_{\mathrm{B}}$ receptors modulate different types of $\mathrm{Ca}^{2+}$ currents in rat nodose ganglion neurons. Neuroscience 1998, 85:939-956.
91. Ricco MM, Kummer W, Biglari B, Myers AC, Undem B]: Interganglionic segregation of distinct vagal afferent fibre phenotypes in guinea-pig airways. J Physiol 1996, 496:52I-530.

92. Lawrence AJ: Neurotransmitter mechanisms of rat vagal afferent neurons. Clin Exp Pharmacol Physiol 1995, 22:869-873.

93. Meeley MP, Underwood MD, Talman WT, Reis DJ: Content and in vitro release of endogenous amino acids in the area of the nucleus of the solitary tract of the rat. I Neurochem 1989, 53:1807-18I7.

94. Wilson CG, Zhang Z, Bonham AC: Non-NMDA receptors transmit cardiopulmonary $C$ fibre input in nucleus tractus solitarii in rats. Physiol 1996, 496:773-785.

95. Aicher SA, Goldberg A, Sharma S, Pickel VM: Mu-opioid receptors are present in vagal afferents and their dendritic targets in the medial nucleus tractus solitarius. I Comp Neurol 2000, 422: $181-190$

96. Undem BJ, Chuaychoo B, Lee MG, Weinreich D, Myers AC, Kollarik $M$ : Subtypes of vagal afferent $C$-fibres in guinea-pig lungs. Physiol 2004, 556:905-917.

97. Lundberg JM, Hokfelt T, Martling CR, Saria A, Cuello C: Substance $P$-immunoreactive sensory nerves in the lower respiratory tract of various mammals including man. Cell Tissue Res 1984, 235:25I-26I.

98. Fischer A, Wussow A, Cryer A, Schmeck B, Noga O, Zweng M, Peiser C, Dinh QT, Heppt W, Groneberg DA: Neuronal plasticity in persistent perennial allergic rhinitis. J Occup Environ Med 2005, 47:20-25

99. Mazzone SB, Mori N, Canning BJ: Synergistic interactions between airway afferent nerve subtypes regulating the cough reflex in guinea-pigs. J Physiol 2005, 569:559-573.
Publish with Biomed Central and every scientist can read your work free of charge

"BioMed Central will be the most significant development for disseminating the results of biomedical research in our lifetime. "

Sir Paul Nurse, Cancer Research UK

Your research papers will be:

- available free of charge to the entire biomedical community

- peer reviewed and published immediately upon acceptance

- cited in PubMed and archived on PubMed Central

- yours - you keep the copyright 